\title{
HUBUNGAN KUALITAS PELAYANAN ANTENATAL CARE DENGAN KEPUASAAN IBU HAMIL
}

\author{
RELATIONSHIP BETWEEN THE QUALITY OF ANTENATAL CARE \\ SERVICES AND THE SATISFACTION OF PREGNANT WOMEN
}

\author{
Nancy Lidya Sampouw \\ Fakultas IImu Keperawatan, Universitas Klabat \\ Email: nancy.sampouw@unklab.ac.id
}

\begin{abstract}
ABSTRAK
Pendahuluan: Kepuasan merupakan tingkat perasaan yang timbul karena kualitas pelayanan yang didapat sama dengan keinginan, kebutuhan, dan harapan pasien. Ibu hamil sebagai penerima pelayanan antenatal care (ANC) di puskesmas membutuhkan pelayanan yang berkualitas. Tujuan: tujuan dari penelitian ini adalah untuk mengetahui hubungan kualitas pelayanan antenatal care dengan kepuasaan ibu hamil. Metode: Metode penelitian ini yaitu deskriptif korelatif. Penelitian ini dilakukan melalui pendekatan cross-sectional. Teknik sampling yang digunakan yaitu total sampling. Sampel penelitian sebanyak 99 responden yaitu seluruh ibu hamil di Puskesmas Bahu. Hasil: Hasil uji statistik kualitas pelayanan yang tertinggi tangibles (bukti fisik) dengan kategori sangat baik (mean 4.58), dan kepuasan ibu hamil aspek tertinggi assurance (jaminan) dengan kategori puas (mean 4.30). Hasil uji Pearson Corellation $\mathrm{p}<.05$ berarti ada hubungan tangibles (bukti fisik) kualitas pelayanan dengan kepuasan ibu hamil, $\mathrm{p}=.05$ berarti tidak ada hubungan reliability (kehandalan) kualitas pelayanan dengan kepuasan ibu hamil, $p>0.05$ berarti tidak ada hubungan responsiveness (daya tanggap) kualitas pelayanan dengan kepuasan ibu hamil, $p<0.05$ berarti ada hubungan assurance (jaminan) kualitas pelayanan dengan kepuasan ibu hamil, $p<0.05$ berarti ada hubungan emphaty (perhatian) kualitas pelayanan dengan kepuasan ibu hamil. Diskusi: Kepada peneliti-peneliti selanjutnya untuk melakukan penelitian pada responden ibu hamil primigravida dan rekomendasi untuk Puskesmas Bahu untuk meningkatkan kehandalan atau kemampuan dalam memberikan pelayanan antenatal care.
\end{abstract}

Kata Kunci: antenatal care, ibu hamil, kepuasan, kualitas pelayanan

\begin{abstract}
Introduction: Satisfaction is the level of feeling that arises because the quality of service obtained is the same as the wishes, needs, and expectations of the patient. Pregnant women as recipients of antenatal care services (ANC) at the community health centers need quality services. The purpose of this study is to determine the relationship between the quality of antenatal care services and the satisfaction of pregnant women. Method: This research method is descriptive correlative. This research was conducted through a cross-sectional approach. The sampling technique used is total sampling. The study sample consisted of 99 respondents, namely all pregnant women at the Puskesmas Bahu. Results: The results of the statistical test of the highest quality of service tangibles (physical evidence) in the very good category (mean 4.58), and the satisfaction of pregnant women the highest aspect of assurance (collateral) with a satisfied category (mean 4.30). Results: The results of the Pearson Corellation $p<.05$ means that there is a tangibles relationship (physical evidence) of service quality with the satisfaction of pregnant women, $p=.05$ means that there is no relationship between reliability (reliability) of service quality and satisfaction of pregnant women, $p>0.05$ means there is no response relationship (responsiveness) quality of service with satisfaction of pregnant women, $p<0.05$ means that there is an assurance relationship (guarantee) of service quality with satisfaction of pregnant women, $p<0.05$ means there is an emphaty (attention) relationship with the quality of service of pregnant women. Discussion: To the next researchers to conduct research on primigravida pregnant women respondents and recommendations for Bahu community health center to improve reliability or ability to provide services.
\end{abstract}

JURNAL

SKOLASTIK KEPERAWATAN

Vol, 4, No. 2

Juli - Desember 2018

ISSN: $2443-0935$

E-ISSN 2443 - 16990 


\section{PENDAHULUAN}

Ibu hamil wajib melakukan pemeriksaan kehamilan untuk memastikan kesehatan ibu dan janin selama masa kehamilan. Hal yang wajib dilakukan oleh ibu hamil yaitu melakukan pemeriksaan selama masa kehamilan untuk mengetahui kesehatan mental dan fisik pada ibu hamil sehingga mampu menghadapi masa kehamilan (Manuaba, 2008). Pemeriksaan kesehatan ibu hamil secara fisik dan mental wajib dilakukan untuk menyelamatkan ibu dan anak dalam masa kehamilan untuk mendeteksi komplikasi (Yeyeh, 2010). Melakukan pemeriksaan selama masa kehamilan merupakan hal yang wajib dilakukan oleh ibu hamil yaitu pemeriksaan secara fisik maupun mental untuk memastikan ibu dan bayi sehat, dapat mendeteksi komplikasi, serta mencegah komplikasi yang dapat mengancam.

Pelayanan pemeriksaan ibu hamil dilakukan oleh tenaga medis yaitu bidan atau dokter dan diukur berdasarkan kemampuan dalam melakukan tugas yang sesuai dengan uraian tugasnya (Notoadmojo, 2010). Bidan atau dokter yang kemampuannya untuk memberikan pelayanan pemeriksaan ibu hamil menjadi unsur untuk memelihara serta meningkatkan kualitas pembangunan kesehatan nasional (Mardiyah, Herawati \& Witcahyo, 2013). Kinerja pelayanan dalam upaya memelihara dan meningkatkan pembangunan kesehatan merupakan kinerja utama bidan dan dokter dalam upaya menurunkan terjadinya komplikasi pada ibu hamil sampai dengan proses kelahiran yang dapat menurunkan Angka Kematian Ibu (AKI) (Endang, 2011). AKI sangat erat kaitannya dengan masa kehamilan, persalinan, dan nifas (Profil Kesehatan Indonesia, 2015). Survei Demografi Kesehatan Indonesia (SDKI) menunjukkan data AKI pada tahun 2012 terjadi kenaikan sebesar 359 per 100.000 Kelahiran Hidup (KH), data ini masih cukup tinggi dibandingkan dengan negara tetangga kawasan ASEAN (Association of South East Asia Nations). Penyebab langsung terjadinya AKI yaitu pendarahan $35 \%$, eklampsi $29 \%$, dan infeksi $4 \%$ (Buku Saku Profil Kesehatan Provinsi Sulawesi Utara, 2012).

$\begin{array}{lrr}\text { Kualitas } & \text { pelayanan } & \text { adalah } \\ \text { pelaksanaan } & \text { kesehatan } & \text { yang }\end{array}$ dilakukan oleh petugas kesehatan yang mana dapat memberikan kebutuhan dan harapan bagi ibu hamil, dan dilakukan sesuai dengan standar pelayanan (Sullvian, Kean \& Cryer, 2009). Penilaian penatalaksanaan yang dilakukan oleh petugas kesehatan untuk kualitas pelayanan bagaimana mereka dapat memberikan standar asuhan kehamilan dalam memantau, memastikan kesehatan ibu hamil serta tumbuh kembang janin di dalam tubuh (Depkes RI, 2010). Pelayanan yang berkualitas tidak hanya ketika petugas memberikan asuhan kehamilan, tetapi dapat memenuhi fasilitas-fasilitas, mengingatkan ibu hamil untuk selalu memeriksaan kehamilannya tiap trimester, dan petugas pelayanan mampu bersikap sopan, baik, tidak memandang tingkat sosial ekonomi, sehingga dapat terciptanya kualitas pelayanan yang baik yang dapat memenuhi kebutuhan 
dan harapan dari ibu hamil (Kemenkes RI, 2013).

Terwujudnya kepuasan ibu hamil dapat dinilai melalui kualitas pelayanan kesehatan yang dilakukan (Wirijadinata, 2009). Dalam era globalisasi kualitas pelayanan menjadi persaingan yang sangat penting sehingga puskesmas diharapkan menjadi tempat pelayanan kesehatan yang dapat memuaskan pelanggannya (Supranto, 2006). Puskesmas yang merupakan salah satu instansi pemerintah dan berperan sebagai tempat pelayanan kesehatan dituntut untuk dapat memenuhi keinginan serta harapan masyarakat sehingga mampu memberikan kepuasan bagi masyarakat (Marniyati, 2016).

Berdasarkan hasil penelitian di Puskesmas Getasan Kabupaten Semarang yang dilakukan oleh Nissa, Surjani, dan Mardiyaningsih (2013) didapatkan data ibu hamil yang tidak melakukan pemeriksaan kehamilan sebanyak 36 orang $(46,44 \%)$. Di Puskesmas Mergangsan Yogyakarta data hasil penelitian masuk dalam kategori tidak puas sebanyak 10 (15,4\%) (Melay, 2013). Data hasil penelitian di Puskesmas Kombos Kecamatan Singkil Kota Manado, sebesar $38(62,3 \%)$ responden menilai baik dalam kualitas pelayanan, dan sebesar 23 (37,7\%)yaitu kualitas pelayanan yang kurang baik (Solang, 2012). Di Puskesmas Karanganyar Kabupaten Purbalingga, hasil wawancara pada 10 ibu hamil yang melakukan pemeriksaan kehamilan sebanyak enam ibu hamil (60\%) petugas melayani dengan penuh perhatian, cepat tanggap, dan ramah, sedangkan petugas yang memberikan pelayanan kurang perhatian, kurang teliti, kurang ramah sebanyak empat ibu hamil (40\%) (Rahayu, Fajarsari, \& Mastuti, 2013).

Berdasarkan observasi awal yang dilakukan oleh peneliti dengan melakukan wawancara dengan beberapa ibu hamil yang datang memeriksakan diri ke Puskesmas Bahu didapati masih ada ibu hamil yang tidak puas dengan kualitas pelayanan antenatal care dan sebagian ada yang merasa puas dengan kualitas pelayanan di Puskesmas Bahu Manado. Dari latar belakang masalah dan hasil observasi maka peneliti tertarik untuk melakukan penelitian tentang "Hubungan Kualitas Pelayanan Antenatal Care (ANC) Dengan Kepuasan Ibu Hamil”.

Masalah utama yang telah diteliti ialah untuk menentukan hubungan kualitas pelayanan antenatal care dengan kepuasan ibu hamil, untuk menjawab masalah ini dirumuskan beberapa pertanyaan berikut:

1. Bagaimana kualitas pelayanan antenatal care.

2. Sejauh mana kepuasan ibu hamil terhadap pelayanan antenatal care.

3. Apakah ada hubungan yang signifikan tentang kualitas pelayanan antenatal care dengan kepuasan ibu hamil dari aspek tangibles (bukti fisik).

4. Apakah ada hubungan yang signifikan tentang kualitas pelayanan antenatal care dengan kepuasan ibu hamil dari aspek reliability (kehandalan).

5. Apakah ada hubungan yang signifikan tentang kualitas pelayanan antenatal care dengan kepuasan ibu hamil dari aspek responsiveness (daya tanggap). 
6. Apakah ada hubungan yang signifikan tentang kualitas pelayanan antenatal care dengan kepuasan ibu hamil dari aspek assurance (jaminan).

7. Apakah ada hubungan yang signifikan tentang kualitas pelayanan antenatal care dengan kepuasan ibu hamil dari aspek emphaty (perhatian).

\section{METODOLOGI PENELITIAN}

Desain penelitian yang digunakan ialah penelitian deskriptif korelasi. Penelitian ini melalui pendekatan cross-sectional yaitu jenis penelitian yang menekankan waktu pengukuran atau observasi data variabel bebas dan terikatpada waktu yang sama. Variabel dalam penelitian ini dibagi dua yaitu variabel terikat (dependent variable), variabel bebas (independent variable). Variabel bebas dalam penelitian ini yaitu kualitas pelayanan, sedangkan variabel terikat yaitu kepuasan ibu hamil.

Data dianalisis menggunakan rumus statistik mean dan pearson correlation untuk mengetahui hubungan antara variabel bebas dan variabel terikat. Nilai $p$-alpha yang digunakan dalam penelitian ini ialah .05 .

Populasi dalam penelitian ini yaitu seluruh ibu hamil yang memeriksakan kehamilannya di Puskesmas Bahu Manado selama periode pengambilan data yaitu bulan Oktober sampai Desember 2017. Metode sampling yang digunakan dalam penelitian ini yaitu purposive sampling. Adapun sampel yang diambil harus memenuhi kriteria sampel yaitu inklusi dan eksklusi. Besar sampel yang digunakan dalam penelitian ini menggunakan rumus Slovin, yaitu diperoleh 99 responden.

Instrumen penelitian berupa kuesioner diadaptasi dari Mandias (2013) yang berhubungan dengan kualitas pelayanan dan kepuasan, yang telah divalidasi dengan nilai Alpha Cronbach 0.93, sehingga kuesioner dinyatakan valid untuk digunakan. Kuesioner dibagi dua bagian, yaitu kuesioner pertama tentang kualitas pelayanan dan kuesioner kedua tentang kepuasan ibu hamil.

Lokasi yang dipilih oleh peneliti untuk melakukan penelitian yaitu di Puskesmas Bahu terletak di Jalan Bunaken Nomor 103 Bahu, Kecamatan Malalayang, Kota Manado, Provinsi Sulawesi Utara. Penelitian dilakukan selama bulan September 2017 sampai April 2018.

\section{HASIL}

Untuk menjawab pernyataan masalah pertama tentang kualitas pelayanan antenatal care maka peneliti menggunakan rumus mean dengan hasil pada Tabel 1. 
Tabel 1. Uji Statistik Mean Kualitas Pelayanan Antenatal Care

\begin{tabular}{|c|c|c|c|c|c|}
\hline & $\mathbf{N}$ & Minimum & Maximum & Mean & Std. Deviation \\
\hline Tangibles (Bukti Fisik) & 99 & 3.25 & 5.00 & 4.58 & .45 \\
\hline Reliability (Kehandalan) & 99 & 1.00 & 5.00 & 4.44 & .64 \\
\hline $\begin{array}{l}\text { Responsiveness } \\
\text { (Daya Tanggap) }\end{array}$ & 99 & 1.50 & 5.00 & 4.27 & .82 \\
\hline Assurance (Jaminan) & 99 & 3.00 & 5.00 & 4.53 & .55 \\
\hline Emphaty (Perhatian) & 99 & 2.00 & 5.00 & 4.36 & .73 \\
\hline Valid N (listwise) & 99 & & & & \\
\hline
\end{tabular}

Uji statistik menunjukan bahwa kualitas pelayanan antenatal care tertinggi dilihat pada aspek tangibles (bukti fisik) dengan kategori sangat baik (mean 4.58), aspek assurance (jaminan) dengan kategori sangat baik (mean 4.53), aspek reliability (kehandalan) dengan kategori baik (mean 4.44), aspek emphaty (perhatian) dengan kategori baik (mean 4.36), dan terendah pada aspek responsiveness (daya tanggap) dengan kategori baik (mean 4.27). Hal ini menunjukkan kualitas pelayanan aspek yang tertinggi ialah aspek tangibles (bukti fisik) dan yang terendah ialah aspek responsiveness (daya tanggap).

Menurut Mandias (2013), salah satu aspek kualitas pelayanan yaitu tangibles (bukti fisik) meliputi bukti fisik dari jasa, yang berupa fasilitas fisik, peralatan yang digunakan, atau penampilan dari personil. Penampilan dan peralatan dan petugas yang memberikan pelayanan. Aspek ini mencakup kondisi fisik, peralatan, serta penampilan petugas karena jasa yang tidak dapat diamati secara langsung. Kenyataan yang berkaitan dengan hal ini mencakup objek yang sangat bervariasi seperti penampilan petugas, tempat duduk, pencahayaan ruangan, brosur, peralatan dan fasilitas yang digunakan. Salah satu faktor untuk memenuhi harapan pelanggan yaitu adanya kualitas pelayanan berupa fasilitas fisik peralatan yang digunakan sehingga dapat memenuhi kebutuhan, keinginan dari pelanggan (Wijaya, 2011).

Penelitian yang dilakukan oleh Rahayu, dkk (2013) tentang kualitas pelayanan antenatal care di Puskesmas Karanganyar Kabupaten Purbalingga, sebanyak 45 orang dengan kategori baik, dan sebanyak 29 orang dengan kategori sangat baik untuk aspek tangibles (bukti fisik). Penelitian ini sejalan dengan Amatiria (2014) kualitas pelayanan di Rumah Sakit Graha Husada Bandar Lampung sebanyak 50 orang menyatakan pelayanannya dari aspek tangibles (bukti fisik), responsiveness (daya tanggap) dan assurance (jaminan) dalam kategori sangat baik.

Berdasarkan penelitian yang telah dilakukan oleh peneliti di Puskesmas Bahu Manado didapati bahwa aspek yang tertinggi ialah aspek tangibles (bukti fisik) karena peralatan yang digunakan memadai, penampilan petugas berupa seragam perawat yang 
digunakan rapih, suasana ruangan yang nyaman sudah sangat baik.

\section{Kepuasan Ibu Hamil}

Untuk menjawab pernyataan masalah kedua tentang sejauh mana kepuasan ibu hamil, maka peneliti menggunakan rumus mean dengan hasil pada Tabel 2

Tabel 2. Uji Statistik Mean Kepuasan Ibu Hamil

\begin{tabular}{llllll} 
& N & $\begin{array}{l}\text { Minimu } \\
\text { m }\end{array}$ & Maximum & Mean & $\begin{array}{l}\text { Std. } \\
\text { Deviation }\end{array}$ \\
\hline $\begin{array}{l}\text { Tangibles (Bukti Fisik) } \\
\begin{array}{l}\text { Reliability } \\
\text { Kehandalan) }\end{array}\end{array}$ & 99 & 2.75 & 5.00 & 4.12 & .51 \\
$\begin{array}{l}\text { Responsiveness } \\
\text { (Daya Tanggap) }\end{array}$ & 99 & 2.00 & 5.00 & 4.13 & .73 \\
$\begin{array}{l}\text { Assurance (Jaminan) } \\
\text { Emphaty (Perhatian) }\end{array}$ & 99 & 2.00 & 5.00 & 4.13 & .73 \\
\begin{tabular}{l} 
Valid N (listwise) \\
\hline
\end{tabular} & 99 & 2.00 & 5.00 & 4.18 & .77 \\
\hline
\end{tabular}

Uji statistik mean menunjukan bahwa kepuasan ibu hamil tertinggi pada aspek assurance (jaminan) dengan kategori puas (mean 4.30), aspek emphaty (perhatian) dengan kategori puas (mean 4.18), aspek reliability (kehandalan) dan aspek responsiveness (daya tanggap) dengan kategori yang sama yaitu puas (mean 4.13), dan terendah pada aspek tangibles (bukti fisik) dengan kategori puas (mean 2.12). Hal ini menunjukan bahwa aspek yang tertinggi yaitu aspek assurance (jaminan), dan yang terendah yaitu aspek tangibles (bukti fisik).

Aspek assurance (jaminan) merupakan salah satu aspek kualitas pelayanan (Mandias, 2013). Jaminan yang berhubungan dengan kemampuan dalam menanam kepercayaan dan keyakinan kepada konsumen. Dalam dimensi ini meliputi kemampuan petugas atas pengetahuan yang tepat serta terampil dalam memberi pelayanan. Dimensi jaminan mencakup pengetahuan dan etika kesopanan dan kemampuan dalam memberikan kepercayaan kepada pelanggan serta keamanan operasional. Keamanan bertujuan untuk meyakinkan pelanggan bahwa pelanggan bebas dari bahaya risiko dan keragu-raguan.

Penelitian ini sejalan dengan Pohan (2007) yang menyatakan bahwa kepuasan timbul akibat pelayanan yang didapat berupa kemampuan petugas atas pengetahuan serta terampil dalam memberi pelayanan melebihi yang diharapkan. Pasien yang merasa puas akan terus memakai pelayanan di tempat yang sama, dan pasien akan merekomendasikan kepada kerabat dan teman-teman, selain itu pasien akan mematuhi pengobatan dan akan datang berobat kembali. Hal yang sama penelitian yang dilakukan oleh Rahayu, dkk (2013) di Puskesmas Karanganyar Kabupaten Purbalingga, bahwa sebanyak 52 orang merasa puas 
dengan pelayanan antenatal care yang dilakukan dengan baik oleh bidan yaitu kemampuan petugas dan pengetahuan yang terampil dari petugas di puskesmas.

Hasil penelitian ini mendukung kedua penelitian tersebut yaitu aspek tertinggi assurance (jaminan). Ibu hamil yang melakukan pemeriksaan di Puskesmas Bahu merasa puas dengan pelayanan petugas medis yaitu para bidan terampil dalam memberi pelayanan serta mamu menjawab pertanyaan para ibu hamil yang artinya bidan memiliki pengetahuan yang baik sesuai dengan bidang pekerjaannya.

\section{Hubungan Kualitas Pelayanan Antenatal Care Dengan Kepuasan Ibu Hamil Ditinjau Dari Aspek Tangibles (Bukti Fisik)}

Untuk menjawab pernyataan masalah ketiga tentang apakah ada hubungan yang signifikan tentang kualitas pelayanan antenatal care dengan kepuasan ibu hamil ditinjau dari aspek tangibles (bukti fisik) dengan hipotesis $\left(\mathrm{H}_{0}\right)$ Tidak ada hubungan yang signifikan tentang kualitas pelayanan dengan kepuasan ibu hamil ditinjau dari aspek tangibles (bukti fisik), peneliti menggunakan rumus Pearson Correlation yang akan dijelaskan pada Tabel 3.

Tabel 3. Hubungan Aspek Tangibles (Bukti Fisik) Kualitas Pelayanan Antenatal Care Dengan Kepuasan Ibu Hamil.

\begin{tabular}{llll} 
& & $\begin{array}{l}\text { Tangibles } \\
\text { (Bukti Fisik) } \\
\text { Kualitas } \\
\text { Pelayanan }\end{array}$ & $\begin{array}{l}\text { Tangibles } \\
\text { (Bukti Fisik) } \\
\text { Kepuasan Ibu } \\
\text { Hamil }\end{array}$ \\
\hline $\begin{array}{l}\text { Tangibles } \\
\text { (Bukti Fisik) }\end{array}$ & $\begin{array}{l}\text { Pearson Correlation } \\
\text { Kualitas Pelayanan }\end{array}$ & 1 & $.399^{* *}$ \\
$\begin{array}{l}\text { Antenatal Care } \\
\text { Tangibles } \\
\text { (Bukti Fisik) }\end{array}$ & $\mathrm{N}$ & & .000 \\
$\begin{array}{l}\text { Kepuasan Ibu } \\
\text { Hamil }\end{array}$ & Pearson Correlation & $.399^{* *}$ & 99 \\
\hline
\end{tabular}

Hasil statistik menunjukan bahwa dari penelitian hubungan tangibles (bukti fisik) kualitas pelayanan antenatal care dengan kepuasan ibu hamil ialah $p=.000<.05$ yang berarti tolak $\mathrm{H}_{0} 1$. Dapat disimpulkan bahwa ada hubungan kualitas pelayanan antenatal care terhadap kepuasan ibu hamil ditinjau dari aspek tangibles (bukti fisik). Dari Tabel 3 menunjukan bahwa antara aspek tangibles (bukti fisik) kualitas pelayanan dengan kepuasan ibu hamil terdapat koefisien korelasi (r) sebesar 0,399 . Hal tersebut berarti bahwa ada korelasi positif antara aspek tangibles (bukti fisik) kualitas pelayanan dengan kepuasan ibu hamil dengan tingkat hubungan korelasi lemah (antara 0,21-0,40). 
Salah satu faktor yang meningkatkan kualitas pelayanan yaitu dengan mengukur kepuasan pasien, kepuasan pasien tergantung dengan bukti layanan langsung yang didapatkan selama melakukan pelayanan seperti kelengkapan alat yang digunakan memadai, kebersihan alat yang digunakan, dan suasana perawatan yang nyaman, sehingga dapat mempengaruhi pasien untuk datang kembali ke tempat yang sama untuk memperoleh pelayanan berikutnya (Yamit, 2010).

Hasil penelitian ini sejalan dengan penelitian yang dilakukan oleh Mursyida, dkk (2012), yang menyatakan bahwa ternyata ada hubungan antara kualitas pelayanan dengan kepuasan ibu hamil yang ditinjau melalui aspek tangibles (bukti fisik) di Puskesmas Tanjung Kabupaten Sampang Madura. Penelitian yang dilakukan Melay (2013), yang menyatakan bahwa ada hubungan antara kualitas pelayanan antenatal care dengan kepuasan ibu hamil yang ditinjau melalui aspek tangibles (bukti fisik) di Puskesmas Mergangsan Yogyakarta.
Berdasarkan penelitian yang dilakukan oleh peneliti di Puskesmas Bahu Manado didapati bahwa kualitas pelayanan antenatal care dengan kepuasan ibu hamil yang ditinjau dari aspek tangibles (bukti fisik) sudah baik di mana sarana pelayanan yang digunakan, kebersihan ruangan pasien, perawat atau bidan dapat membuat suasana perawatan yang nyaman, penampilan menarik oleh petugas kesehatan, sehingga pasien termotivasi untuk kembali memeriksakan kehamilanya di puskesmas yang sama.

\section{Hubungan Kualitas Pelayanan Antenatal Care Dengan Kepuasan Ibu Hamil Ditinjau Dari Aspek Reliability (Kehandalan)}

Untuk menjawab pernyataan masalah keempat tentang apakah ada hubungan kualitas pelayanan antenatal care dengan kepuasan ibu hamil yang ditinjau dari aspek reliability (kehandalan), peneliti menggunakan rumus Pearson Correlation yang akan dijelaskan pada Tabel 4.

Tabel 4. Hubungan Aspek Reliability (Kehandalan) Kualitas Pelayanan Antenatal Care Dengan Kepuasan Ibu Hamil.

\begin{tabular}{|c|c|c|c|}
\hline & & $\begin{array}{l}\text { Reliability } \\
\text { (Kehandalan) } \\
\text { Kualitas } \\
\text { Pelayanan }\end{array}$ & $\begin{array}{l}\text { Reliability } \\
\text { (Kehandalan) } \\
\text { Kepuasan Ibu } \\
\text { Hamil }\end{array}$ \\
\hline Reliability & Pearson Correlation & 1 & $.198^{*}$ \\
\hline (Kehandalan) & Sig. (2-tailed) & & .050 \\
\hline Kualitas Pelayanan & $\mathrm{N}$ & 99 & 99 \\
\hline Reliability & Pearson Correlation & $.198^{*}$ & 1 \\
\hline (Kehandalan) & Sig. (2-tailed) & .050 & \\
\hline Kepuasan Ibu Hamil & $\mathrm{N}$ & 99 & 99 \\
\hline
\end{tabular}


Hasil uji statistik menunjukan bahwa hasil dari penelitian hubungan reliability (kehandalan) kualitas pelayanan dengan kepuasan ibu hamil ialah nilai $p=.05$ yang berarti terima $\mathrm{H}_{0} 2$, dengan demikian dapat disimpulkan bahwa tidak ada hubungan kualitas pelayanan antenatal care terhadap kepuasan ibu hamil ditinjau dari aspek reliability (kehandalan).

Wiyono (2007) menyatakan pelayanan pada ibu hamil sangat penting, dan pelayanan tersebut diberikan selama masa kehamilan, dan untuk menjadikan pelayanan bermutu maka pelayanan yang diberikan harus dapat memberikan kepuasan kepada setiap pelanggan atau pasien sesuai dengan standar profesi dan kode etik yang telah ditetapkan yaitu sesuai dengan standar pelayanan. Penelitian ini sejalan dengan Amatiria (2016) bahwa tidak ada hubungan antara kualitas pelayanan dengan kepuasan ibu hamil di Rumah Sakit Graha Husada Bandar Lampung.

Berdasarkan penelitian yang dilakukan oleh peneliti di Puskesmas Bahu Manado didapati bahwa melalui aspek reliability (kehandalan) kurang baik karena bidan kurang handal dan tidak mampu memberikan pelayanan yang akurat dan handal. Bidan tidak dapat memberikan pelayanan yang sesuai dengan waktu yang yang dijanjikan.

\section{Hubungan Kualitas Pelayanan Antenatal Care Dengan Kepuasan Ibu Hamil Ditinjau Dari Aspek Responsiveness (Daya Tanggap)}

Untuk menjawab pernyataan masalah kelima tentang apakah ada hubungan tentang kualitas pelayanan antenatal care terhadap kepuasan ibu hamil yang ditinjau dari aspek responsiveness (daya tanggap), peneliti menggunakan rumus Pearson Correlation yang akan dijelaskan pada Tabel 5.

Tabel 5. Hubungan Aspek Responsiveness (Daya Tanggap) Kualitas Pelayanan Antenatal Care Dengan Kepuasan Ibu Hamil.

\begin{tabular}{|c|c|c|c|}
\hline & & $\begin{array}{l}\text { Responsiveness } \\
\text { (Daya Tanggap) } \\
\text { Kualitas } \\
\text { Pelayanan }\end{array}$ & $\begin{array}{l}\text { Responsiveness } \\
\text { (Daya Tanggap) } \\
\text { Kepuasan Ibu } \\
\text { Hamil }\end{array}$ \\
\hline Responsiveness & Pearson Correlation & 1 & .193 \\
\hline (Daya Tanggap) & Sig. (2-tailed) & & .056 \\
\hline Kualitas Pelayanan & $\mathrm{N}$ & 99 & 99 \\
\hline Responsiveness & Pearson Correlation & .193 & 1 \\
\hline (Daya Tanggap) & Sig. (2-tailed) & .056 & \\
\hline Kepuasan Ibu hamil & $\mathrm{N}$ & 99 & 99 \\
\hline
\end{tabular}


ibu hamil ialah nilai $\mathrm{p}=.056>.05$ yang berarti terima $\mathrm{H}_{0} 3$. Dapat disimpulkan bahwa tidak ada hubungan kualitas pelayanan antenatal care terhadap kepuasan ibu hamil ditinjau dari aspek responsiveness (daya tanggap).

Menurut Nursalam (2008), kepuasan merupakan perasaan senang seseorang yang berasal dari perbandingan seseorang antara kesenangan terhadap aktivitas dan suatu produk harapannya. Pohan (2007), menyatakan bahwa kepuasan timbul akibat pelayanan yang didapatkan sama atau melebihi yang diharapkan, sehingga pasien akan merasa puas dan akan terus memakai pelayanan ditepat yang sama dan mereka akan merekomendasikan kepada kerabat dan teman-teman, selain itu pasien akan mematuhi pengobatan dan akan datang berobat kembali.

Hal ini sejalan dengan penelitian yang dilakukan oleh Mursyida, dkk (2012), melalui aspek responsiveness (daya tanggap) bahwa tidak ada hubungan tentang kualitas pelayanan antenatal care dengan kepuasan ibu hamil di Puskesmas Tanjung Kabupaten Sampang Madura. Penelitian ini sejalan dengan Erlina (2011) melalui aspek responsiveness (daya tanggap) bahwa tidak ada hubungan kualitas pelayanan antenatal care dengan kepuasan pasien di Puskesmas Kota Pangkalpinang.

Berdasarkan penelitian yang dilakukan oleh peneliti di Puskesmas Bahu Manado didapati bahwa pada aspek responsiveness (daya tanggap) masih perlu ditingkatkan di mana dalam memberikan respon positif terhadap keluhan pasien, memberikan bantuan yang cepat ketika pasien membutuhkan pertolongan, memberikan pelayanan yang ramah, serta tanggap dalam memberikan informasi tentang perawatan kepada pasien atau keluarga.

\section{Hubungan Kualitas Pelayanan Antenatal Care Dengan Kepuasan Ibu Hamil Ditinjau Dari Aspek Assurance (Jaminan)}

Untuk menjawab pernyataan masalah keenam tentang apakah ada hubungan tentang kualitas pelayanan antenatal care terhadap kepuasan ibu hamil ditinjau dari aspek assurance (jaminan), peneliti menggunakan rumus Pearson Correlation yang akan dijelaskan pada Tabel 6 .

Tabel 6. Hubungan Aspek Assurance (Jaminan) Kualitas Pelayanan Antenatal Care Dengan Kepuasan Ibu Hamil.

\begin{tabular}{llll}
\hline & & $\begin{array}{l}\text { Assurance } \\
\text { (Jaminan) } \\
\text { Kualitas Pelayanan }\end{array}$ & $\begin{array}{l}\text { Assurance } \\
\text { (Jaminan) } \\
\text { Kepuasan Ibu Hamil }\end{array}$ \\
\hline $\begin{array}{llll}\text { Assurance } \\
\text { (Jaminan) }\end{array}$ & Pearson Correlation & 1 & $.248^{*}$ \\
Kualitas Pelayanan & Sig. (2-tailed) & & .013 \\
$\begin{array}{l}\text { Assurance } \\
\text { (Jaminan) }\end{array}$ & $\mathrm{N}$ & 99 & 99 \\
Kepuasan Ibu Hamil & Pearson Correlation & $.248^{*}$ & 1 \\
\hline
\end{tabular}


Hasil uji statistik menunjukan bahwa hasil dari penelitian hubungan aspek assurance (jaminan) kualitas pelayanan antenatal care dengan kepuasan ibu hamil ialah nilai $p=.013$ $<.05$ yang berarti tolak $\mathrm{H}_{0} 4$. Dapat disimpulkan bahwa ada hubungan kualitas pelayanan antenatal care terhadap kepuasan ibu hamil ditinjau dari aspek assurance (jaminan). Dari Tabel 6 menunjukan bahwa antara aspek assurance (jaminan) kualitas pelayanan dengan kepuasan ibu hamil terdapat koefisien korelasi (r) sebesar 0,248 . Hal tersebut berarti bahwa ada korelasi positif antara aspek assurance (jaminan) kualitas pelayanan dengan kepuasan ibu hamil dengan tingkat hubungan korelasi lemah (antara 0,21-0,40).

Salah satu faktor yang berpengaruh dalam kualitas pelayanan dengan kepuasan pasien yaitu dengan adanya jaminan yang diberikan, dengan demikian hal tersebut dapat memenuhi harapan dan kebutuhan pasien dalam suatu layanan, jika dalam pelayanan tidak ada jaminan kepuasan maka pasien tidak akan kembali memeriksakan kehamilannya ditempat yang sama (Tjiptono, 2012).

Hal ini sejalan dengan penelitian yang dilakukan oleh Amatiria (2016) di Rumah Sakit Graha Husada Bandar Lampung melalui aspek assurance (jaminan) bahwa ada hubungan kualitas pelayanan antenatal care

Tabel 7. Hubungan Emphaty (Perhatian) Kualitas Pelayanan Antenatal Care Dengan Kepuasan Ibu Hamil. dengan kepuasan ibu hamil. Penelitian ini sejalan dengan Mursyida, dkk (2012) bahwa ada hubungan kualitas pelayanan antenatal care dengan kepuasan ibu hamil di Puskesmas Tanjung Kabupaten Sampang Madura.

Berdasarkan penelitian yang dilakukan peneliti di Puskesmas Bahu Manado didapati pada aspek assurance (jaminan) sudah dilakukan dengan baik karena perawat terampil dan mengetahui cara melayani pasien dengan baik, bersikap sopan dan ramah, memberikan keterangan yang jelas saat melakukan pelayanan, memberikan rasa aman dan nyaman kepada pasien.

\section{Hubungan Kualitas Pelayanan Antenatal Care Dengan Kepuasan Ibu Hamil Ditinjau Dari Aspek Emphaty (Perhatian)}

Untuk menjawab pernyataan masalah ketujuh tentang apakah ada hubungan yang signifikan tentang kualitas pelayanan antenatal care dengan kepuasan ibu hamil ditinjau dari aspek emphaty (perhatian) dan $\mathrm{H}_{0} 5$ : Tidak ada hubungan yang signifikan tentang kualitas pelayanan antenatal care terhadap kepuasan ibu hamil ditinjau dari aspek emphaty (perhatian), peneliti menggunakan rumus Pearson Correlation yang akan dijelaskan pada Tabel 7.

\begin{tabular}{llll}
\hline & & $\begin{array}{l}\text { Emphaty } \\
\text { (Perhatian) } \\
\text { Kualitas Pelayanan }\end{array}$ & $\begin{array}{l}\text { Emphaty } \\
\text { (Perhatian) } \\
\text { Kepuasan Ibu Hamil }\end{array}$ \\
\hline $\begin{array}{l}\text { Emphaty } \\
\text { (Perhatian) }\end{array}$ & 1 & $.223^{*}$ \\
Kualitas Pelayanan & Pearson Correlation & & .026 \\
$\begin{array}{l}\text { Emphaty } \\
\text { (Perhatian) }\end{array}$ & Sig. (2-tailed) & 99 & 99 \\
Kepuasan Ibu Hamil & Pearson Correlation & $.223^{*}$ & 1 \\
\hline & Sig. (2-tailed) & .026 & 99 \\
\hline
\end{tabular}


Hasil uji statistik menunjukan bahwa hasil dari penelitian hubungan aspek emphaty (perhatian) dengan kualitas pelayanan antenatal care dengan kepuasan ibu hamil ialah nilai $p=.026$ $<.05$ yang berarti tolak $\mathrm{H}_{0} 5$. Dapat disimpulkan bahwa ada hubungan kualitas pelayanan antenatal care terhadap kepuasan ibu hamil ditinjau dari aspek emphaty (perhatian). Dari Tabel 7 menunjukan bahwa antara aspek emphaty (perhatian). kualitas pelayanan dengan kepuasan ibu hamil terdapat koefisien korelasi (r) sebesar 0,223 . Hal tersebut berarti bahwa ada korelasi positif antara aspek emphaty (perhatian). kualitas pelayanan dengan kepuasan ibu hamil dengan tingkat hubungan korelasi lemah (antara 0,21-0,40).

Sikap loyalitas pasien selalu berbanding lurus dengan kepuasan yang didapatkan dari adanya perhatian yang baik dari petugas kesehatan, dan menunjukkan bahwa dengan adanya kepuasan yang didapat maka pelanggan akan memutuskan kembali memeriksakan kehamilannya (Yamit, 2010). Dalam upaya mempertahankan kualitas pelayanan serta mempertahankan pasien yang sebagai pelanggan, sebaiknya pelayanan kesehatan yang diberikan oleh petugas kesehatan harus dapat membangun loyalitas dengan memberikan kepuasan kepada pasien (Supranto, 2006).

Hal ini sejalan dengan penelitian yang dilakukan oleh Solang, dkk (2012) melalui aspek emphaty bahwa ada hubungan kualitas pelayanan dengan kepuasan ibu hamil di Puskesmas Kombos Kecamatan Singkil Kota Manado. Penelitian ini sejalan dengan Rahayu, dkk (2013) bahwa ada hubungan kualitas pelayanan dengan kepuasan ibu hamil di Puskesmas Karanganyar Kabupaten Purbalingga.

Berdasarkan hasil penelitian yang telah dilakukan peneliti di Puskesmas Bahu Manado yang ditinjau dari aspek perhatian atau empati sudah baik karena kemampuan komunikasi yang dilakukan oleh bidan baik dalam melayani, petugas kesehatan memberikan informasi pelayanan jika ada hal yang baru, bidan dapat menjaga hubungan yang baik dengan pasien, bidan dapat mengerti keinginan pasien, dan memberikan pelayanan yang ramah.

\section{KESIMPULAN REKOMENDASI}

DAN

\section{Kesimpulan}

Berdasarkan hasil dari penelitian yang telah dilakukan, peneliti mengambil kesimpulan, bahwa:

1. Kualitas pelayanan antenatal care dengan nilai tertinggi yaitu aspek tangibles (bukti fisik) dengan kategori sangat baik (mean 4.58), dan nilai terendah yaitu aspek responsiveness (daya tanggap) dengan kategori baik (mean 4.27).

2. Kepuasan ibu hamil dengan nilai tertinggi yaitu aspek assurance (jaminan) kategori puas (mean 4.30), dan nilai terendah yaitu aspek tangibles (bukti fisik) tetapi dengan kategori puas (mean 4.12).

3. Ada hubungan kualitas pelayanan antenatal care terhadap kepuasan ibu hamil yang ditinjau dari aspek tangibles (bukti fisik) dengan nilai $\mathrm{p}=.000$ $<.05$ dengan nilai $r=0.399$ (korelasi lemah). 
4. Tidak ada hubungan kualitas pelayanan antenatal care terhadap kepuasan ibu hamil yang ditinjau dari aspek reliability (kehandalan) dengan nilai $p=.05$ dan $\mathrm{r}=0.198$ (tidak ada hubungan atau korelasi sangat lemah).

5. Tidak ada hubungan kualitas pelayanan antenatal care terhadap kepuasan ibu hamil yang ditinjau dari aspek responsiveness (daya tanggap) dengan nilai $p=.056>.05$ dan $\mathrm{r}$ $=0.193$ (korelasi tidak ada hubungan atau korelasi sangat lemah).

6. Ada hubungan kualitas pelayanan antenatal care terhadap kepuasan ibu hamil yang ditinjau dari aspek assurance (jaminan) dengan nilai $p=.013<.05$ dan $\mathrm{r}=0.248$ (korelasi lemah).

7. Ada hubungan kualitas pelayanan antenatal care terhadap kepuasan ibu hamil yang ditinjau dari aspek emphaty (perhatian) atau empati dengan nilai $p=.026<.05$ dan $\mathrm{r}=0.223$ (korelasi lemah).

Berdasarkan hasil pengolahan data dan pengujian hipotesa, peneliti mengambil kesimpulan bahwa kualitas pelayanan antenatal care yang tertinggi tangibles (bukti fisik) dengan kategori sangat baik, kepuasan ibu hamil dengan kategori puas. Hubungan kualitas pelayanan antenatal care dengan kepuasan ibu hamil ditinjau dari aspek tangibles (bukti fisik), assurance (jaminan) dan emphaty (perhatian), kemudian hubungan kualitas pelayanan dengan kepuasan ibu hamil yang ditinjau dari aspek reliability (kehandalan) dan responsiveness (daya tanggap) tidak ada hubungan.

\section{Rekomendasi}

Bagi Puskemas Bahu hasil dari penelitian ini diharapkan dapat menjadi bahan informasi yang bermanfaat untuk meningkatkan kualitas pelayanan dan kepuasan khususnya pada aspek reliability (kehandalan) dan responsiveness (daya tanggap). Bagi ibu hamil hasil dari penelitian ini diharapkan dapat memberikan informasi kepada ibu hamil melalui pelayanan antenatal care yang dilakukan oleh petugas kesehatan (dokter, bidan, perawat), dan dapat diharapkan memberikan kepuasan serta memotivasi ibu hamil agar rajin memeriksakan kehamilannya.

\section{DAFTAR PUSTAKA}

Ahira, A. (2013). Pengertian pelayanan. Diakses dari http://www.anneahira.com/peng ertian-pelayanan.html

Amatiria, G. (2016). Hubungan kualitas pelayanan dengan kepuasan pasien. Jurnal Keperawatan. XII. (1): 106-111. Diakses dari: http://ejurnal.poltekkestjk.ac.id/index.php/JKEP/article/ view/366

Azwar, A. (2007). Pengantar administrasi kesehatan. Jakarta: Binarupa Aksara.

Bartini. (2012). Antenatal care focus. Jakarta: Nuha Medica.

Buku Saku Profil Kesehatan Provinsi Sulawesi Utara. (2012). Manado: 
Dinas Kesehatan Provinsi Sulawesi Utara. Diakses dari: http://www.depkes.go.id/resourc es/download/profil/PROFIL_KE S_PROVINSI_2012/24_Profil_ Kes.Prov.SulawesiUtara_2012.p df

Depkes RI. (2007). Pedoman pelayanan kebidanan dasar. Jakarta.

Depkes RI. (2010). Pedoman pemantauan wilayah setempat kesehatan ibu dan anak. Jakarta: Departement Kesehatan Republik Indonesia.

Endang, R. (2011). Evaluasi kinerja bidan puskesmas dalam pelayanan di Kecamatan Banjasari Kota Surakarta. Skripsi: Program pascasarjana Universitas Sebelas Maret Surakarta.

Erlina, E. (2011). Analisis kualitas pelayanan terhadap kepuasan pasien di unit pelayanan teknis (UPT) puskesmas dinas kesehatan Kota Pangkalpinag tahun 2011. Skripsi: Program Pascasarjana Universitas Terbuka Jakarta. Diakses dari: http://repository.ut.ac.id/649/

Hasibuan. (2007). Manajemen sumber daya manusia. Jakarta: Bumi Aksara.

Hendroyono, A. (2011). Mutu pelayanan kesehatan. Jakarta: Salemba Medica.

Imbalao, S. (2010). Jaminan mutu layanan kesehatan: Dasar-dasar pengertian dan penerapan. Jakarta: EGC.
Irawan, H. (2009). 10 prinsisp kepuasan pelanggan. Jakarta: Elex Media Komputindo.

Juliana, E. (2008). Manajemen pelayanan kebidanan. Jakarta: EGC.

Kamus Besar Bahasa Indonesia. (2008). Jakarta: Gramedia Pustaka Utama.

Kemenkes RI. (2013). Buku saku pelayanan kesehatan ibu di fasilitas kesehatan dasar dan rujukan (Pedoman bagi tenaga kesehatan). Edisi pertama.

Kotler \& Amstrong. (2008). Prinsipprinsip pemasaran. Jakarta: Erlangga.

Mandias, R. (2013). Analisis hubungan pelayanan kesehatan terhadap kepuasan pasien rawat inap RSUP PROF Dr. R. D. Kandou Manado.Skripsi: Fakultas Ilmu Keperawatan Universitas Klabat.

Manuaba. (2008). Ilmu kebidanan, kandungan dan keluarga berencana. Jakarta: EGC.

Mardiyah, U. L., Herawati, Y. T., \& Witcahyo, E. (2013). Faktor yang berhubungan dengan pemanfaatan pelayanan oleh ibu hamil di wilayah kerja puskesmas Tempurejo Kabupaten Jember. Jember: Universitas Jember.

Marniyati, L., Saleh, I., Bambang, B., \&Soebyakto. (2016). Pelayanan berkualitas dalam meningkatkan deteksi risiko tinggi pada ibu 
hamil oleh tenaga kesehatan di puskesmas Sako, Sosial, Sei Baung, dan Sei Selincah di Kota Palembang. 1(3) :355-362. Diakses dari: http://ejournal.unsri.ac.id/index. $\mathrm{php} / \mathrm{jkk} /$ article/download/2852/p df

Maulana. (2008). Penyakit kehamilan dan pengobatannya. Yogyakarta: Katahati.

Marwati, F., Fauziah. N. K., \&Thamrin. H. (2016). Analisis kualitas pelayanan puskesmas terhadap kepuasan ibu hamil di Kota Pangkalpinang Tahun 2015. Jurnal Kedokteran dan Kesehatan. 3(1): 363-371. Diakses dari: http://ejournal.unsri.ac.id/index. php/jkk/article/view/2854

Melay, S. (2013). Hubungan kualitas pelayanan dengan kepuasan ibu hamil terhadap pelayanan di Puskesmas Merangsan. Skripsi: Sekolah Tinggi Ilmu Kesehatan Aisyiyah Yogyakarta.

Mufdillah, H. (2010). Konsep kebidanan. Mitra Cendekia: Yogyakarta.

Mursyida, R. F., Marwani, A., \& Agushybana, F. (2012). Kepuasan ibu hamil dan persepsi kualitas pelayanan di Puskesmas Tanjung Kabupaten Sampang Madura.Jurnal Media Kesehatan Masyarakat Indonesia. 11. (2). Diakses dari: http://ejournal.undip.ac.id/index. php/mkmi/article/view/5395
Mutahar, R. (2010). Analisis determinan pemanfaatan layanan antenatal di Sumatera Selatan.

Naariyong, S., Poudel, C. K., Rahman, M., Yasuoka, J., Otsuka, K., \&Jimba, M. (2012). Quality of antenatal care services in the Birim North Distric of Ghana: Contribution of the community-based health planning and services program. Ghana: Matern Child Health.

Nissa, A. A., Surjani., \& Mardiyaningsih, E. (2013). Gambaran kepuasan ibu hamil terhadap pelayanan di Puskesmas Getasan Kabupaten Semarang. Jurnal Keperawatan Maternitas. 1(1): 21-27. Diakses dari: http://download.portalgaruda.org /article.php?article $=129054 \& \mathrm{val}$ $=5088$

Notoadmojo, S. (2010). Ilmu perilaku kesehatan. Jakarta: PT. Rhineka Cipta.

Nursalam \& Effendi, F. (2008). Pendidikan dalam keperawatan. Jakarta: Salemba Medika

Pakage, A. L. (2015). Hubungan kinerja bidan dalam pelayanan dengan kunjungan k-4 pada ibu hamil di Kabupaten Nabire, Papua tahun 2014. Skripsi: Sekolah tinggi ilmu kesehatan Ngudi Waluyo Ungaran.

Pantikawati, Ika, \& Saryono. (2010). Asuhan kehamilan I. Yogyakarta: Nuha Medika.

Pohan, I. S. (2007). Jaminan mutu kesehatan: dasar-dasarr 
pengertian dan penerapan. Jakarta: EGC.

Prawirohardjo. (2007). Ilmu kandungan. Jakarta: Yayasan Bina Pustaka.

Prawirohardjo, S. (2012). Ilmu kebidanan. Jakarta: PT. Bina Pustaka.

Profil Kesehatan Indonesia. (2015). Jakarta: Kementrian Kesehatan RI. Diakses dari: http://www.depkes.go.id/resourc es/download/pusdatin/profilkesehatan-indonesia/profilkesehatan-indonesia-2014.pdf

Rahayu, L. D. P., Fajarsari, D., \& Mastuti, S. (2013). Hubungan kualitas pelayanan dengan tingkat kepuasan ibu hamil di Puskesmas Karanganyar Kabupaten Purbalingga. Jurnal Ilmiah Kebidanan. 6(2): 106-115. Diakses dari: http://www.ojs.akbidylpp.ac.id/i ndex.php/Prada/article/download /174/138

Riduwan, M, B, A. (2009). Pengantar statistika sosial 2. Bandung: Alfabet.

Saleh. (2010). Public service communication. Malang: UMM Press.

Salmah. (2006). Asuhan kebidanan antenatal. Jakarta: EGC.

Sarwono, J. \& Budiono, H. (2012). Statistik terapan: aplikasi untuk riset skripsi, tesis, dan disertasi (menggunakan SPSS, AMOS, dan Excel) Jakarta: PT. Elex Media Komputindo.
Solang, S., Lohoraung, A., \&Purwandari, A. (2012). Hubungan kepuasan dengan frekuensi kunjungan ibu hamil di puskesmas Kombos Kecamatan Singkil Kota Manado. Jurnal Gizido. 1. (4) :349-357. Diakses dari:

http://ejurnal.poltekkesmanado.a c.id/index.php/gizido/article/dow nload/26/74

Sugiyono. (2009). Metodelogi penelitian kuantitatif kualitatif dan $R \& D$. Bandung: Alfabeta.

Sullvian, A., Kean, L., \& Cryer, A. (2009). Panduan pemeriksaan antenatal. Jakarta: EGC.

Supranto. (2006). Hasil survey indeks kepuasan masyarakat terhadap pelayanan rawat jalan puskesmas idaman di Kabupaten jombang. Jombang.

Supranto, J. (2006). Pengukuran tingkat kepuasan pelanggan (untuk menaikkan pangsa pasar). Rhineka Cipta: Jakarta.

Suryawati. (2011). Kepuasan pasien rumah sakit (Tinjauan teoritis dan penerapannya pada penelitian.

Suyanto. (2011). Metodelogi dan aplikasi penelitian keperawatan. Yogyakarta: Nuha Medika. Werdha (PSTW) Khusnul Khotimah Pekanbaru.

Tangklisan, H. N. S. (2007). Manajemen public. Jakarta: Grasindo. 
Tjiptono. (2012). Service management mewujudkan layanan prima. Yogyakarta: CV Andi Offset.

Triatmodjo, Y. (2011). Mengukur kepuasan pelanggan. Diakses dari:

https://triatmojo.wordpress.com/ 2006/09/24/mengukur-kepuasanpelanggan/

Utama, I. B. R. (2014). Pengantar industri pariwisata. Yogyakarta: Deepublish.

Walyani, E. S. (2015). Perawatan kehamilan \& menyusui anak pertama agar bayi lahir dan tumbuh sehat. Yogyakarta: Pustaka Baru Press.

Wijaya, T. (2011). Manajamen kualitas jasa. Jakarta barat: PT Indeks Kembangan.

Wijono. (2007). Manajemen mutu pelayanan kesehatan. Surabaya: Airlangga Universitas Press.
Winarni. (2014). Kepuasan ibu hamil terhadap pelayanan oleh bidan diwilayah kerja puskesmas Ngoresan.Jurnal Kepuasan Ibu hamil Terhadap Pelayanan. 2(XI) :69-78. Diakses dari: http://download.portalgaruda.org /article.php?article $=340912 \&$ val $=5466$

Wirijadinata, J. J. (2009). Manajemen kepuasan pelanggan atau masyarakat. Jurnal kesehatan. (IV) :1-21. Diakses dari: https://usepmulyana.files.wordpr ess.com/2009/02/manajemenkepuasan-pelanggan-ataumasyarakat.pdf

Yamin. (2010). Manajemen kualitas produk dan jasa. Yogyakarta: Ekonisia.

Yeyeh. (2010). Asuhan kehamilan I. Jakarta: Trans Info Medika. 